\title{
Ownership Structure, Earnings Manipulation, and Organizational Performance: The Case of Jordanian Insurance Organizations
}

\author{
Raed ALQIREM${ }^{1}$, Malik ABU AFIFA ${ }^{2}$, Isam SALEH ${ }^{3}$, Fadi HANIAH ${ }^{4}$
}

Received: September 01, 2020 Revised: October 26, 2020 Accepted: November 05, 2020

\begin{abstract}
This study aims to investigate the direct relationship between ownership structure, earnings manipulation, and organizational performance, and then examine the mediating effect of earnings manipulation in the relationship between ownership structure and organizational performance. This study collected and analyzed secondary data published in financial reports related to all insurance organizations listed in the Jordanian market during the study period (from 2009 until 2018). A panel data analysis was conducted, giving a total of 200 observations. The findings of this study concluded that ownership concentration, foreign ownership, and organization size affect organizational performance proxied by ROA, ROE, and EPS, more specifically, ownership concentration and organization size have a positive effect, whereas foreign ownership has a negative effect. At the same time, board of director ownership, organizational ownership, and CEO compensation did not affect organizational performance. Next, the board of director ownership, ownership concentration, foreign ownership, and CEO compensation affect earnings manipulation separately. In addition, earnings manipulation positively affects organizational performance proxied by ROA, ROE and EPS. This means that the higher the earnings manipulation is, the higher the organizational performance is. Finally, earnings manipulation mediates the relationship between ownership concentration and foreign ownership of ownership structure, and organizational performance.
\end{abstract}

Keywords: Earnings Management, Ownership Structure, Firms Performance, Insurance Companies, Jordanian Market

JEL Classification Code: M41, G40, G41, G32

\section{Introduction}

Recently, ownership structure is an important issue that appears after the separation of ownership from management. Its importance increased at the beginning of the last century with the increase in the number of large organizations, and the expansion of economic activity, as well as the increase in the movement of foreign investments in both local and global

${ }^{1}$ First Author and Corresponding Author. MIS Department, Faculty of Business, Al-Zaytoonah University of Jordan, Jordan [Postal Address: Amman 11733, Jordan] Email: drraed@zuj.edu.jo

${ }^{2}$ Department of Accounting, Faculty of Business, Al-Zaytoonah University of Jordan, Amman, Jordan. Email: M.abuafifa@zuj.edu.jo ${ }^{3}$ Department of Accounting, Faculty of Business, Al-Zaytoonah University of Jordan, Amman, Jordan. Email: i.saleh@zuj.edu.jo ${ }^{4}$ Department of Accounting, Faculty of Business, The World Islamic Sciences and Education University, Amman, Jordan.

Email: fadiacc2008@yahoo.com

(C) Copyright: The Author(s)

This is an Open Access article distributed under the terms of the Creative Commons Attribution Non-Commercial License (https://creativecommons.org/licenses/by-nc/4.0/) which permits unrestricted non-commercial use, distribution, and reproduction in any medium, provided the original work is properly cited. markets (Berle \& Means, 1932; Jensen \& Meckling, 1976). The ownership structure is a tool to control the performance and work of the executive management to reduce agency costs that are linked with the separation of ownership from management (Gyampah et al., 2019). The separation of ownership from management aims to protect shareholders, especially individual shareholders, through reducing practices that involve conflicts of interest in organizations, where individual shareholders do not have sufficient control in organizations and their impact on the board of directors will be limited (Pérez et al., 2019). This separation allows managers in an organization to conduct business by adopting real practical methods that seek to improve the performance.

Owners of an organization may include directors, shareholders, government entities, and others, such as the founders. According to the agency theory, several categories of shareholders can affect the managers' efficiency, which in turn affects the organizational performance (Bassey et al., 2019; Gyampah et al., 2019). Bassey et al. (2019) and Kao et al. (2019) indicated that an ownership structure positively affects the organizational performance when it supports the control level in an organization and thus 
improves the performance. For example, the greater the managerial ownership, the more the organizational performance will improve because the manager(s) will try to make good decisions in the interest of the organization and avoid conflicts of interest, as well as trying to improve the mechanisms they are able to control, and thus improve the performance.

Gyampah et al. (2019) indicated that ownership structure affects organizational performance and noted that organizational performance in locally-owned organizations is greater than in foreign-owned organizations because locally-owned organizations have a higher operational flexibility compared to foreign-owned ones. On the contrary, Pérez et al. (2019) argued that high ownership concentration in an ownership structure affects organizational performance negatively, since it affects an independence level which impacts organizational decisions and therefore performance. Prior studies, such as Morck et al. (1988), McConnell and Servaes (1990), Short and Keasey (1999) and Severin (2001) argued that there is no clear relationship between the categories of shareholders and the organizational performance. Severin (2001) and Chancharat-S and Chancharat-N (2019) found that there is no significant relationship between ownership structure and organizational performance in developing countries because organizations in these countries are generally smaller than those in developed countries, and this influences on their board independence and governance level.

Recent studies by Almasarwah (2019) and Saona et al. (2019) indicated that ownership concentration positively affects earnings management by the discretionary accruals model, since ownership concentration increases the managerial opportunistic behavior in organizations. However, Saona et al. (2019) indicated that there is a significant negative relationship between insiders' ownership, the controlling shareholder, and earnings manipulation; in this case, high insider ownership and a majority controlling shareholder support the governance system, which contributes to improving the independency level in an organization. The greater proportion of independent directors oversees managers more efficiently, and therefore earnings manipulation will be decreased (Al-Absy et al., 2020; Huynh, 2020). Ding et al. (2007) confirmed that the relationship between ownership concentration and earnings manipulation is an inverted U-shape. Privately-owned organizations tend to increase their accounting earnings more than state-owned organizations, while the relationship between ownership concentration and earnings manipulation - taking into account both discretionary accruals and non-operating transactions - is stronger in state-owned organizations compared to privately-owned ones.

Therefore, the current study aims to investigate the relationship between ownership structure, earnings manipulation, and organizational performance. In addition, this study investigates the role of earnings manipulation as a mediator between ownership structure and organizational performance. Empirical evidence has been collected from the Jordanian market as an example of a developing market; more specifically, from insurance organizations in Jordan. The Jordanian insurance sector is one of the most important sectors in the Jordanian market, where the total paid up capital of organizations listed in this sector until 2020 came to JD271.3 million. Recently, its importance has increased, as a result of the environmental uncertainty that affects the Jordanian market (Jaloudi, 2019). It provides financial protection for various other economic sectors and thus its link with the performance of other sectors is very close. Therefore, this study chose this sector in order to identify the determinants of performance of the Jordanian insurance organizations, focusing on their ownership structure and earnings manipulation.

From the context, the contribution of this study can represent through. Firstly, prior studies focused on studying the relationship between these contexts in developed markets, and limited attempts have been made that examined this issue in developing markets, such as the Jordanian market, especially in insurance organizations. Secondly, we can also note that prior studies shared different visions about the relationship between these concepts, which is still not very clear. Thus, this study aims to provide more explanations through the use of empirical evidence about the relationship between ownership structure, earnings manipulation, and organizational performance, as well as the role of earnings manipulation as a mediator. Thirdly, this study adds to the global literature in several ways. To begin with, the current study is the first of its kind to explore earnings manipulation as a mediator between ownership structure and organizational performance. In particular, the empirical literature (e.g., Al-Mousawi \& Al-Thuneibat, 2011; Al-Khabash \& Al-Thuneibat, 2009) has documented that most Jordanian organizations have practiced earnings manipulation in their statements. As the consequence of such a practice, the value of an organization would decrease, along with its transactions, and its reputation (Dang et al., 2020; Huynh \& Nguyen, 2019). Furthermore, this study adds to the literature by showing the explanatory power of ownership structure in developing markets.

\section{Literature Review and Hypotheses}

An agency approach addresses the conflicts of interest between shareholders and management (Berle \& Means, 1932; Bolton \& Scharfstein, 1990). An agency approach is a contract between the owners of organizations and another party (the agent), to transmit management of organizations' interests of principal, which includes 
Raed ALQIREM, Malik ABU AFIFA, Isam SALEH, Fadi HANIAH /

distribution of the responsibilities and authorizations in organizations (Jensen \& Meckling, 1976). The main issue with the agency approach is agency costs; Bassey et al. (2019) and Gyampah et al. (2019) argued that several categories of shareholders will contribute to solve this issue, as they work on improving managers' efficiency and the control level in organizations, and therefore the performance is improved. In addition, Tangjitprom (2012) stated that the improvement of the managers' efficiency by several categories of shareholders reduces the earnings manipulation in financial reporting, and thus the performance is improved. The next three sections present the relationship between ownership structure and earnings manipulation, ownership structure, and organizational performance, and finally the examination of the mediating role of earnings manipulation between ownership structure and organizational performance.

\subsection{Ownership Structure and Earnings Manipulation}

Prior studies (e.g., Affan et al., 2017) pointed out that several categories of shareholders and ownership concentration contribute to improving the supervision of management, and therefore the quality of financial reporting. Almasarwah (2019) indicated that ownership structure is a main element in the evaluation of financial reporting, which enhances the effectiveness and efficiency of performance indicators. The ownership structure influences the managers' behavior, and this contributes to reducing agency issues and minimizing conflicts of interest between shareholders and management (Sirat, 2012). Improving the level of control over the managers' behavior reduces earnings manipulation, and thus increases the quality of financial reporting.

Furthermore, prior studies have shown that there is a positive relationship between $\mathrm{CEO}$ and managerial ownership and earnings manipulation, since they are motivated to increase earnings and thus obtain the maximum benefit (Ogbonnaya et al., 2016; Guna \& Herawaty, 2010). Guna and Herawaty (2010) also added that, as a governance mechanism, the ownership concentration enhances auditor independence and audit quality, and therefore auditor independence and audit quality affect earnings manipulation negatively. Besides, Bao and Lewellyn (2017) and Alexander (2019) argued that controlling shareholders influences managers and thus earnings manipulation because they aim to maximize the return on their investment. Wiranata and Nugrahanti (2013) also argued that greater foreign ownership in an organization refers to appointing more foreign representatives within an organization. They work on balancing the interests of management and shareholders to limit manipulation of earnings and improve the quality of financial reporting.
Based on the above, the current study proposed the following hypothesis:

H1: There is a relationship between ownership structure and earnings manipulation.

\subsection{Earnings Manipulation and Organizational Performance}

Providing incorrect accounting information can mislead the users in an organization, since it influences decisionmaking, and organizational performance could drop or improve, based on this incorrect data (Chintrakarn et al., 2018). Walker (2013) argued that organizational decisions are linked to managers' behavior and personal incentives, and thus affect performance. Prior research found that there are two incentives for managers to manipulate earnings, namely, opportunistic and beneficial incentives (Almasarwah, 2019; Mostafa, 2020). Opportunistic earnings manipulation can be defined as managing earnings to achieve private goals (Sakaki et al., 2017), while beneficial earnings manipulation can be defined as managing earnings in order to achieve investors' objectives (Mellado-Cid et al., 2018). For example, managers can manipulate earnings through reducing taxable income, showing the organization's strong ability to balance returns and risks, increasing stock separation, and increasing managers' compensations (Al Saedi, 2018; Chandren et al., 2018).

Based on previous studies, earnings manipulation generally aims to achieve one of three goals, namely, increase profits, reduce profits, or smooth income by attempting to reduce deviations (Ronen \& Yaari, 2008; Healy \& Wahlen, 1999). Managers can practice earnings manipulation to reach their goals by impacting the cash flow from normal business operations in order to manipulate reported income. Also, they can alter the level of accruals in order to obtain the desired earnings level, using executives' judgments, which are related to accruals in financial reporting (Almasarwah, 2019; Alsufy et al., 2020).

In terms of the relationship between earnings manipulation and organizational performance, Alareeni (2018) argued that the size of an organization, an organization's growth, and its profitability are linked to earnings manipulation by accruals. Degeorge et al. (1999) remarked that larger organizations manage earnings by accruals to avoid losses and practice more earnings manipulation by accruals compared to other organizations (Jensen \& Meckling, 1976). Alareeni (2018) pointed out there is a negative relationship between an organization's growth - using the total assets growth - and earnings manipulation by accruals, since an organization with greater growth reduces the need for managers to manipulate earnings. On the contrary, Meek et al. (2007) and Sayari et al. (2013) remarked that larger organizations have greater 
commitment, and thus they practice earnings manipulation by accruals less, while returns on their shares increase.

Furthermore, Press and Weintrop (1990) and Mohrman (1996) confirmed that there is a positive relationship between debt level and the practices of earnings manipulation by accruals, as organizations aim to reduce the effect of this debt on their profitability through manipulating their earnings by accruals. Other studies, like Shirzad and Haghighi (2015), mentioned that a higher debt level has a negative effect on these practices, where a higher debt level limits the capacity of executives in terms of managing earnings. However, some studies, such as Carslaw (1988), Thomas (1989) and Burgstahler and Dichev (1997), found that there is a positive relationship between earnings manipulation by accruals and an organization's profitability, since managers use earnings manipulation by accruals to increase profits through converting losses into profits, thus improving the organization's image. Meanwhile, Gong et al. (2008), Manzano et al. (2014), Momente et al. (2015), Mostafa and Ibrahim (2019), and Mostafa (2020) remarked that managers use earnings manipulation by accruals to reduce an organization's profits in order to avoid paying taxes. On this note, Arif et al. (2011) also mentioned that earnings manipulation by accruals does not affect dividend policy and profitability.

Based on the above, the current study proposed the second hypothesis as follows:

H2: There is a relationship between earnings manipulation and organizational performance.

\subsection{Ownership Structure and Organizational Performance Mediated by Earnings Manipulation}

Oswald and Jahera (1991) and Han and Suk (1998) found a significant relationship between ownership structure and organizational performance. Han and Suk (1998) and Lappalainen and Niskanen (2012) mentioned that insider ownership affects the organizational performance positively. Han and Suk (1998) also remarked that organizational ownership is positively linked to stock returns, where organizational shareholders are active in controlling management, and therefore improve organizational performance. On the contrary, Lappalainen and Niskanen (2012) documented that organizations with high organizational ownership ratios are less profitable and concluded that organizations with external board members are less profitable. This may refer to the organization's board independence and governance practices that affect the levels of control in developing countries compared to developed countries. Mahrani and Soewarno (2018) mentioned that there is a positive link between good corporate governance and financial performance, and earnings manipulation mediates the relationship between good corporate governance and financial performance. They also noted that earnings manipulation negatively affects financial performance.

Based on the discussion above, the current study aims to examine the relationship between ownership structure and organizational performance, mediated by earnings manipulation. Therefore, the current study proposed the following hypotheses:

H3: There is a relationship between ownership structure and organizational performance.

H4: Earnings manipulation mediates a relationship between ownership structure and organizational performance.

\section{Research Methodology}

\subsection{Population and Study Sample}

The study population included all insurance organizations listed in the Jordanian market between 2009 and 2018 . Twenty-four insurance organizations were listed in 2019. However, the financial reports of only 20 were available, therefore the study sample consists of 20 insurance organizations. This yielded a total of 200 observations for each variable.

\subsection{Study Data and Analysis Method}

This study collected and analyzed secondary data published in financial reports related to the targeted organizations during the study period (from 2009 until 2018). Therefore, it was deemed appropriate for a panel data analysis to be used in this study.

\subsection{Study Model}

The current study aims to investigate the relationship between ownership structure, earnings manipulation, and organizational performance, and then to further examine the role of earnings manipulation as a mediator between ownership structure and organizational performance. The study model is presented in the following figure (See Figure 1).

The study model set the following parameters: ownership structure (OS) as an independent variable, organizational performance (OP) as a dependent variable, and earnings manipulation (EM) as a mediator variable. At the same time, this study used two controlled variables, namely, organization size (Size), and administrative compensations $(\mathrm{COM})$. The next sections present the calculations relevant to each variable. 


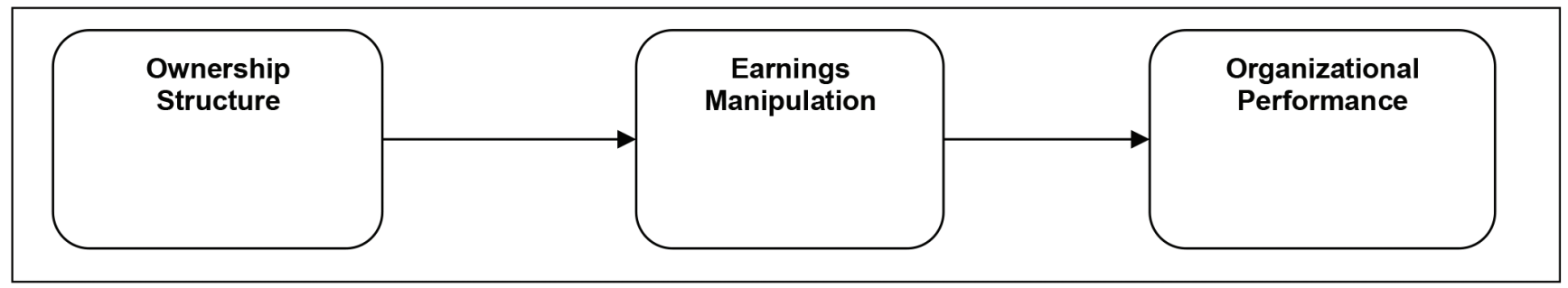

Figure 1: Study Model

\section{Ownership Structure}

The subject of ownership structure dates back to the early work of Berle and Means (1932) that focused on separation of ownership from control in their book entitled The Modern Corporation and Private Property, where they indicated that an increase in the size of ownership coincides with distribution of shares among large number of small holders; this can have adverse effects, leading to conflicts of interests between small holders that don't have adequate control power and enormous holders that distinguish strong concentrated ownership (Mizruchi, 2004). Jensen and Meckling (1976) discussed the relation between agency costs and the fraction of equity held by managers and defined ownership structure as the distribution of equity with regards to votes and capital, as well as the identity of the equity owners. In addition, the authors pointed out another kind of agency problem, which represents conflicts of interest arising from delegating decision-making authority from a principal to the agent, will mostly acts for his personal interests. The shareholders can reduce agency costs among compensation and incentive policies to the managers.

Considering the above conflicts interest the current study determined the following dimensions of ownership structures:

- Board of directors' ownership: this was determined by dividing the total number of shares owned by the board of directors to total number of outstanding shares (Andreou et al., 2014) as follows:

$$
\text { BODi.t }=\frac{\text { TOBODi.t }}{\text { CSi.t }}
$$

where BODi.t is board of director's ownership ratio for the organization $i$ in the year $t$; TOBODi.t is the total shares owned by board of directors for the organization $i$ in the year t; and CSi.t is total outstanding shares for the organization i in the year $t$.

- Concentration of ownership: this was calculated through dividing the majority of shares (5\% and more) held by few owners by the total number of outstanding shares. The equation for the concentration of ownership is presented as follows:

$$
\text { CONi.t }=\frac{\text { TOCONi.t }}{\text { CSi.t }}
$$

where CONi.t is concentrated ownership ratio for the organization $\mathrm{i}$ in the year $\mathrm{t}$; TOCONi.t is the total majority of shares (5\% and more) are held by few owners for the organization $\mathrm{i}$ in the year $\mathrm{t}$; and CSi.t is total outstanding shares for the organization $i$ in the year $t$.

- Organizational ownership: the current study measured organizational ownership through dividing the shares owned by general and private companies by the total outstanding shares (Affan et al., 2017) as follow:

$$
\text { INSTi.t }=\frac{\text { TOINSTi.t }}{\text { CSi.t }}
$$

where INSTi.t is organizational ownership ratio for the organization $\mathrm{i}$ in the year $\mathrm{t}$; TOINSTi.t is the total shares owned by domestic general and private companies for the organization $\mathrm{i}$ in the year $\mathrm{t}$; and CSi.t is total outstanding shares for the organization $i$ in the year $t$.

- Foreign ownership: this was calculated by dividing shares owned by foreign investors by the number of total outstanding shares (Farooque et al., 2007) as follows:

$$
\text { FOREIGNi.t }=\frac{\text { TOFOREIGNi.t }}{\text { CSi.t }}
$$

where FOREIGNi.t is foreign ownership ratio for the organization $\mathrm{i}$ in the year $\mathrm{t}$; TOFOREIGNi.t is the total shares owned by foreigner's investors for the organization $\mathrm{i}$ in the year t; and CSi.t is total outstanding shares for the organization $i$ in the year $t$.

\section{Earnings Manipulation}

This study used a modified Jones model to measure EM practice in an organization. This modified Jones model measured the non-discretionary accruals in order to detect EM (Jones, 1991; Dechow et al., 1995). It has often been used by previous studies (e.g., Almarayeh et al., 2020; Almasarwah, 
2019; Chang \& Sun, 2009; Niu, 2006), that discussed that this model as the best in this area. The modified Jones model calculates EM through the following steps:

Step 1: Calculation of total accruals by finding the difference between operating net profit and operating cash flow through the following equation:

$$
\text { TACCi.t }=\text { ONIi.t }- \text { OCFi.t }
$$

where TACCi.t is total accruals for the organization $i$ for the year $\mathrm{t}$; ONIi.t is operating net profit for the organization $\mathrm{i}$ for the year t; as well as OCFi.t is operating cash from for the organization $\mathrm{i}$ for the year $\mathrm{t}$.

Step 2: Non-discretionary accruals (NDACCi.t) calculated by the following regression equation of the sample for each year.

$$
\begin{aligned}
& \text { TACCi.t/Ai.t-1 = a1(1/Ai.t-1)+a2(( } \mathbf{\Delta} \text { REVi.t- } \mathbf{\Delta} \text { RECi.t }) / \\
& \text { Ai.t-1) }+ \text { a3 (PPEi.t/Ai.t-1) }+\varepsilon
\end{aligned}
$$

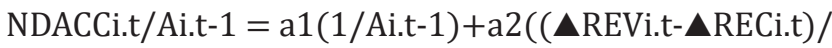

$$
\begin{aligned}
& \text { Ai.t-1) + a3 (PPEi.t/Ai.t-1) }
\end{aligned}
$$

where TACCi.t is total accruals for the organization $i$ for the year t; $\Delta \mathrm{REVi}$.t is the change in revenue for the organization $i$ for the year $t ; \Delta R E C i . t$ is the change in receivables for the organization i for the year t; PPEi.t is the properties, plants and equipment for the organization $i$ for the year t; Ai.t-1 is total assets for the organization $i$ for the year $t-1 ; \varepsilon$ is the random error; and NDACCi.t is non-discretionary accruals for the organization $i$ for the year $t$.

Step 3: Discretionary accruals by the following equation:

$$
\text { DACCi.t }=(\text { TACCi.t/Ai.t-1) }-(\text { NDACCi.t/Ai.t-1) }
$$

where DACCi.t is discretionary accruals for the organization $\mathrm{i}$ for the year $\mathrm{t}$.

\section{Organizational Performance}

The current study measured OP from the financial side, by using three financial proxies for OP, namely, return on assets (ROA), return on equity (ROE), and earnings per share (EPS). These proxies have been used extensively by previous studies (e.g. Nassar, 2018; Obuobi et al., 2020) to measure OP. The equations of ROA, ROE, and EPS are presented as follows:

$$
\text { ROA i.t }=\frac{\text { Net Income i.t }}{\text { Total Assets i.t }}
$$

where ROA i.t $=$ ROA for the organization $\mathrm{i}$ for the year $\mathrm{t}$; Net Income i.t $=$ net income for the organization $\mathrm{i}$ for the year $\mathrm{t}$; and Total Assets i.t $=$ total assets for the organization $\mathrm{i}$ for the year $\mathrm{t}$.

$$
\text { ROEi.t }=\frac{\text { Net Income i.t }}{\text { Tota; Equity i.t }}
$$

where ROE i.t $=$ ROE for the organization $\mathrm{i}$ for the year $\mathrm{t}$; Net Income i.t $=$ net income for the organization $i$ for the year $t$; and Total Equity i.t = total equity for the organization $\mathrm{i}$ for the year $\mathrm{t}$.

$$
\text { EPSi.t }=\frac{\text { Net Income }- \text { Dividend on Preferred Stock i.t }}{\text { Average outstanding shares i.t }}
$$

where EPS i.t $=$ EPS for the organization i for the year $t$; Net Income - Dividend on Preferred Stock i.t $=$ net income for the organization $\mathrm{i}$ for the year $\mathrm{t}$ less dividend on preferred stock for the same organization $i$ in the same year $t$; and Average outstanding shares i.t $=$ (beginning outstanding shares plus ending outstanding shares) for the organization $\mathrm{i}$ for the year $\mathrm{t}$ dividing by 2 .

\section{Control Variables}

Two control variables are included in this study, namely, organization size and administrative compensations. Organization size (Size) was measured by using the natural logarithm of total assets for each organization during the study period (e.g., Ariyani et al., 2018; Devin et al., 2019; Endri \& Fathony, 2020; Weerathunga et al., 2020; Afifa et al., 2020). The administrative compensations (which include wages and benefits for $\mathrm{CEO})(\mathrm{COM})$ variable were calculated using the natural logarithm of total wages and benefits the CEO of each organization was paid during the study period.

\section{Data Analysis and Testing}

\subsection{Data Validity}

Linear regression is associated with a number of criteria that must be met before testing the hypotheses. It's important to conduct the following tests in order to judge the validity of the data.

\subsection{Multicollinearity}

The validity of the regression model depends on the independence of each of the independent variables. If this criterion is not met, the model cannot be considered appropriate. Multiple linear correlation problems arise when 
the correlation strength between the independent variables used in the regression model is greater than 0.8 . These affect the process of estimating model parameters; therefore it affects the efficiency of the model in general (Gujarati, 2004). Two methods are used to detect this multiple linear correlation issue. The first is the Pearson correlation test. Regarding this test, Bryman and Cramer (2002) stated that, if the correlation coefficient exceeds 0.8 between the independent study variables, this is an indication of the presence of multicollinearity. The second method is to find the Variance Inflation Factor (VIF) and tolerance, which shows how the high correlation increases the instability of the estimated coefficients and is a calculation performed for each variable separately.

The results displayed in Table (1) show no multicollinearity among independent variables, since the correlation coefficient appears between -0.378 and 0.673 . Also, Table (1) presents the VIF and tolerance values for all variables in the study model, which came to less than 10 , and more than 0.2 respectively. This means that the panel data model in the current study did not suffer from any multicollinearity problems (See Table 1).

\subsection{Stationary Test}

Time series analysis is one of the statistical methods that address the behavior of phenomena and their interpretation over extended time periods. The stability of time series is an important topic with many applications that adopt panel data, as the instability of data gives misleading results for the values of $R^{2}$ and the value of $F$.

In order to test the stability of this time series, a unit root test was performed. A Levin-Lin-Chu test was performed to test whether the study variables contained the unit root; when the Levin-Lin-Chu test detects a unit root, the significance level is expected to be above $5 \%$. Table 2 showed that $p$-value for all variables is less than $5 \%$, and this ensures that all variables are stable over time, and therefore it is possible to reject the of the existence of a unit root (See Table 2).

\subsection{Descriptive results}

Table 2 also shows the findings of descriptive analysis tests. It shows that the mean size of the organizations examined during the study period was 17.0864 with an $\mathrm{SD}$ of 0.6458 . The mean of COM was 0.0454 with an $\mathrm{SD}$ of 0.0214 . The highest value for ownership structure factors refers to ownership concentration where the mean concentration was 0.6395 with an SD of 0.1897 , which means that big investors own more than $5 \%$ of insurance organizations, and the nature of their ownership structure is more concentrated than dispersed. In addition, the mean of Bod was also high (0.5512) with an SD of 0.2052, while the mean of foreign ownership was 0.2357 with an SD of 0.2998. Organizational ownership had the lowest investment in insurance organizations with a mean Inst of 0.1949 and an SD of 0.1950 (See Table 2).

Also, the three indicators (ROA, ROE, and EPS) illustrate the financial performance for these organizations during the period studied. The mean ROA was 0.0230 with an SD of 0.0575, while the means ROE and EPS were 0.1057 and 0.0464 with SD of 0.2525 and 0.1185 respectively. The mean EM was -0.0046 with an SD of 0.0027. This indicates that, overall, there were negative earnings management practices in these organizations during the period studied, as they aimed to reduce their income instead of increasing it. However, these practices are relatively few because the mean value was closer to 0 during the study period studied.

Table 1: Correlation matrix

\begin{tabular}{|c|c|c|c|c|c|c|c|c|c|}
\hline Variable & Size & COM & Bod & Con & Inst & Foreign & EM & VIF & Tolerance \\
\hline Size & 1.000 & & & & & & & 1.377 & 0.726 \\
\hline COM & -0.080 & 1.000 & & & & & & 1.449 & 0.690 \\
\hline Bod & 0.257 & 0.080 & 1.000 & & & & & 1.894 & 0.528 \\
\hline Con & 0.241 & 0.230 & 0.673 & 1.000 & & & & 3.383 & 0.296 \\
\hline Inst & 0.288 & -0.378 & 0.203 & 0.204 & 1.000 & & & 1.959 & 0.510 \\
\hline Foreign & 0.269 & 0.160 & 0.444 & 0.633 & -0.213 & 1.000 & & 2.527 & 0.396 \\
\hline EM & 0.282 & 0.192 & 0.115 & 0.236 & 0.148 & 0.029 & 1.000 & 1.231 & 0.812 \\
\hline
\end{tabular}




\subsection{Regression Models Analysis}

A panel data model contains observations of multiple phenomena obtained over multiple time periods for the same organization by combining time-series and crosssectional data. The idea behind combining time-series and cross-sectional data is to arrive at a better model estimate; in addition, this model provides more informative data, more variability, less collinearity among variables, more degrees of freedom, and more efficiency (Baltagi, 2005). The methodology of the study relied on collecting financial data through time series data extending from the year 2009 to the year 2018, which was also cross-sectional data from the study sample including 20 organizations. Thus, each organization represents a cross-section.

Regression models are divided in two types of models: the Fixed Effect model, and the Random Effects model. A Hausman test was conducted to choose one of the two aforementioned models to test the panel data. The null hypothesis $(\mathrm{H} 0)$ indicates the random effects model should be selected versus the alternative hypothesis (H1) that indicates the fixed effects model should be accepted. If the value of Prob-value exceeds 5\%, the random effects model will be chosen; and then if the value of Prob-value is less than $5 \%$, the fixed effect approach will be selected (Baltagi, 2005).

Table 3 presents the values of the Chi-Sq Statistic for all regression models, which amounted to 11.544 , 9.563, and 12.191, respectively, with the value of Prob-value reaching $0.073,0.214$, and 0.094 respectively. Therefore, we accepted the null hypothesis, and that the appropriate estimation method was a random effects model. In the other words, this study adopted a random effect approach in order to test its hypotheses and achieve its objectives (See Table 3).

The first objective of this study was to examine the effect of ownership structure on earning manipulation. The second objective was to examine the effect of earning manipulation on organizational performance. The third objective was to examine the effect of ownership structure on organizational performance. The fourth objective was to examine the effect of earning manipulation as a mediator between ownership structure and organizational performance. Therefore, four different regression models were estimated. The following sections present the results of the regression models.

Table 2: Levin-Lin-Chu test and descriptive statistics

\begin{tabular}{|l|c|c|c|c|}
\hline \multirow{2}{*}{ Variable } & \multicolumn{2}{|c|}{ Levin-Lin-Chu test } & \multicolumn{2}{c|}{ Descriptive statistics } \\
\cline { 2 - 5 } & P-Value & Statistic & Mean & St. Deviation (SD) \\
\hline Size & 0.003 & -2.735 & 17.0864 & 0.6458 \\
\hline COM & 0.000 & -4.180 & 0.0454 & 0.0214 \\
\hline Bod & 0.000 & -58.263 & 0.5512 & 0.2052 \\
\hline Con & 0.000 & -2.962 & 0.6395 & 0.1897 \\
\hline Inst & 0.000 & -27.778 & 0.1949 & 0.1950 \\
\hline Foreign & 0.002 & -2.948 & 0.2357 & 0.2998 \\
\hline EM & 0.000 & -9.597 & -0.0046 & 0.0027 \\
\hline ROA & 0.000 & -10.124 & 0.0230 & 0.1408 \\
\hline ROE & 0.000 & -35.270 & 0.1057 & 0.2525 \\
\hline EPS & 0.000 & -5.565 & 0.0464 & 0.1185 \\
\hline
\end{tabular}

Table 3: Hausman test

\begin{tabular}{|l|c|c|c|}
\hline Test Summary & Chi-Sq. Statistic & Chi-Sq. & Prob. \\
\hline Dependent variable: ROA & 11.544 & 7 & 0.073 \\
\hline Dependent variable: ROE & 9.563 & 7 & 0.214 \\
\hline Dependent variable: EPS & 12.191 & 7 & 0.094 \\
\hline
\end{tabular}


Raed ALQIREM, Malik ABU AFIFA, Isam SALEH, Fadi HANIAH /

H1: There is a relationship between ownership structure and earnings manipulation.

Table 4 shows that the $\mathrm{R}^{2}$ value of the model was 0.253 , which means that the model explains $25.3 \%$ from the changes in earnings manipulation, whereas Prob (F-statistic) was 0.000 , meaning all ownership structures with each other in the model affected the earnings manipulation. Consequently, the results reveal that the board of director ownership, ownership concentration, foreign ownership, and CEO compensation affect earnings manipulation separately. At the same time, the results indicate that organizational ownership and size did not affect earnings manipulation. In addition, the table suggests that ownership concentration positively affects management practices that are representative of earnings manipulation. As a conclusion, the first null hypothesis was partially rejected (See Table 4).

Furthermore, according to the regression analysis, the relationship between CEO compensation and earnings manipulation is positive, which enhances and explains the positive relation between ownership concentration and earning manipulation. This result coincides with results from some other studies (e.g., Saona et al., 2019). However, at the same time these results are consistent with other studies that indicated ownership concentration improves the supervision of management and quality of financial reporting (e.g., Affan et al., 2017).

This study also showed that the greater the ownership by the board of directors is, the lower the earnings manipulation is. This is because greater board of director ownership contributes to support the control practices (e.g. governance) that limit the opportunistic practices in organizations. Although the contribution of foreign ownership is relatively small (the mean came to only $23.57 \%$ from total ownership structure), the table indicates that this relationship is negative and this may refer to the pressure exerted by foreign investors on an organization's management in order to change its opportunistic practices.

H2: There is a relationship between earnings manipulation and organizational performance.

Table 5 presents the results of the analysis of the relationship between earnings manipulation and organizational performance. The results showed that the $\mathrm{R}^{2}$ of the effect of earnings manipulation on ROA, ROE and EPS were $0.118,0.121$, and 0.170 , respectively. The Probvalue (F-statistic) was less than $1 \%$ for the three models and the relation was positive. Thus, the second null hypothesis was rejected (See Table 5). In other words, earnings manipulation affects organizational performance positively. This could be attributed to the failure on the part of the board of directors to appropriately supervise and control function in the organization. Although this link is positive, previous studies have shown that the correlation between earnings manipulation and organizational performance can have negative effects in the long term (Mahrani \& Soewarno, 2018). However, the results of the current analysis agree with those of Gong et al. (2008), Manzano et al. (2014), Momente et al. (2015), Mostafa and Ibrahim (2019), and Mostafa (2020); at the same time, they do not agree with Carslaw (1988), Thomas (1989), Burgstahler and Dichev (1997), Press and Weintrop (1990), Mohrman (1996) and Arif et al. (2011), who noted that organizational performance is negatively affected by earnings manipulation, because managers focused on earning manipulation practices to decrease the profits of their companies and achieve their personal goals.

H3: There is a relationship between ownership structure and organizational performance.

Table 6 reveals that the $\mathrm{R}^{2}$ of the effect of ownership structure on ROA, ROA, and EPS were 0.184, 0.134, and 0.150 , respectively, and the Prob (F-statistic) was less than $1 \%$ for the three models. The results showed that ownership concentration, foreign ownership, and organization size affect ROA, ROE and EPS separately. At the same time, the results reported that board of director ownership, organizational ownership and CEO compensation did not have an effect on ROA, ROE and EPS. In addition, the table suggests that ownership concentration affects organizational performance positively - as represented by ROA, ROE and EPS - while the effect of foreign ownership is negative. Finally, the third null hypothesis was partially rejected (See Table 6). These results match the findings of recent literature, such as Gyampah et al. (2019), Bassey et al. (2019), Kao et al. (2019), and Pérez et al. (2019), but not those of other empirical studies, such as Severin (2001) and Chancharat-S and Chancharat-N (2019).

H4: Earnings manipulation mediates the relationship between ownership structure and organizational performance.

Table 7 shows that insertion of earnings manipulation as a mediating factor improves the ability of regression models; its inclusion raised the $\mathrm{R}^{2}$ for the three models from 0.184 , 0.134 , and 0.150 to $0.219,0.162$, and 0.212 , respectively, and also the Prob value (F-statistic) was less than 1\% for the three models. Consequently, the results still revealed that ownership concentration, foreign ownership and organization size affect ROA, ROE and EPS separately. At the same time, board of director ownership, organizational ownership and CEO compensation still did not affect ROA, ROE and EPS. In addition, from the table, it's clear that ownership concentration positively affects organizational performance, as represented by ROA, ROE and EPS, while the effect of foreign ownership is negative. Finally, Table 7 indicates that earnings manipulation mediates the relationship between ownership concentration and foreign ownership of ownership structure, and organizational performance, and thus the fourth null hypothesis was partially rejected (See Table 7). 
Table 4: Regression results of the first hypothesis

\begin{tabular}{|c|c|c|c|c|}
\hline Variable & Coefficient & Std. Error & t-Statistic & Prob. \\
\hline C & -0.067 & 0.010 & -6.775 & $0.000^{* * *}$ \\
\hline Size & 0.000 & 0.001 & 0.472 & 0.638 \\
\hline COM & 0.005 & 0.001 & 5.050 & $0.000^{* * *}$ \\
\hline Bod & -0.004 & 0.002 & -1.815 & $0.071^{*}$ \\
\hline Con & 0.010 & 0.003 & 3.648 & $0.000^{* * *}$ \\
\hline Inst & -0.002 & 0.002 & -0.918 & 0.360 \\
\hline Foreign & -0.005 & 0.002 & -3.464 & $0.001^{* * *}$ \\
\hline R-squared & 0.253 & & & \\
\hline Adjusted R-squared & 0.229 & & & \\
\hline F-statistic & 10.619 & & & \\
\hline Prob (F-statistic) & $0.000^{* * *}$ & & & \\
\hline
\end{tabular}

Note: ${ }^{*},{ }^{* *},{ }^{* * *}=p$-value $<.10, .05, .01$.

Table 5: Regression results of the second hypothesis

\begin{tabular}{|c|c|c|c|c|c|}
\hline DV & Variable & Coefficient & Std. Error & t-Statistic & Prob. \\
\hline \multirow{8}{*}{ ROA } & $\mathrm{C}$ & -0.356 & 0.144 & -2.475 & $0.014^{* *}$ \\
\hline & Size & 0.020 & 0.009 & 2.102 & $0.037^{* *}$ \\
\hline & $\mathrm{COM}$ & 0.004 & 0.012 & 0.337 & 0.736 \\
\hline & EM & 2.992 & 0.936 & 3.197 & $0.002^{* * *}$ \\
\hline & R-squared & \multicolumn{4}{|l|}{0.118} \\
\hline & Adjusted R-squared & \multicolumn{4}{|l|}{0.104} \\
\hline & F-statistic & \multicolumn{4}{|l|}{8.495} \\
\hline & Prob(F-statistic) & \multicolumn{4}{|l|}{$0.000^{* * *}$} \\
\hline \multirow{8}{*}{ ROE } & $\mathrm{C}$ & -0.709 & 0.314 & -2.258 & $0.025^{* *}$ \\
\hline & Size & 0.056 & 0.020 & 2.787 & $0.006^{* * *}$ \\
\hline & $\mathrm{COM}$ & -0.016 & 0.027 & -0.583 & 0.560 \\
\hline & EM & 6.767 & 2.090 & 3.238 & $0.001^{* * *}$ \\
\hline & R-squared & \multicolumn{4}{|l|}{0.121} \\
\hline & Adjusted R-squared & \multicolumn{4}{|l|}{0.107} \\
\hline & F-statistic & \multicolumn{4}{|l|}{8.390} \\
\hline & Prob(F-statistic) & \multicolumn{4}{|l|}{$0.000^{* * *}$} \\
\hline \multirow{8}{*}{ EPS } & $\mathrm{C}$ & -1.003 & 0.302 & -3.327 & $0.001^{* * *}$ \\
\hline & Size & 0.073 & 0.019 & 3.771 & $0.000^{* * *}$ \\
\hline & COM & -0.014 & 0.025 & -0.544 & 0.587 \\
\hline & EM & 6.924 & 1.915 & 3.616 & $0.000^{* * *}$ \\
\hline & R-squared & \multicolumn{4}{|l|}{0.170} \\
\hline & Adjusted R-squared & \multicolumn{4}{|l|}{0.157} \\
\hline & F-statistic & \multicolumn{4}{|l|}{12.999} \\
\hline & Prob(F-statistic) & \multicolumn{4}{|l|}{$0.000^{* * *}$} \\
\hline
\end{tabular}

Note: ${ }^{*},{ }^{* *},{ }^{* * *}=\mathrm{p}$-value $<.10, .05, .01$. 
Table 6: Regression results of the third hypothesis

\begin{tabular}{|c|c|c|c|c|c|}
\hline DV & Variable & Coefficient & Std. Error & t-Statistic & Prob. \\
\hline \multirow{11}{*}{ ROA } & $\mathrm{C}$ & -0.635 & 0.150 & -4.219 & $0.000^{* * *}$ \\
\hline & Size & 0.026 & 0.010 & 2.647 & $0.009^{* * *}$ \\
\hline & COM & 0.010 & 0.012 & 0.848 & 0.398 \\
\hline & Bod & -0.013 & 0.023 & -0.547 & 0.585 \\
\hline & Con & 0.165 & 0.034 & 4.852 & $0.000^{* * *}$ \\
\hline & Inst & -0.034 & 0.031 & -1.107 & 0.270 \\
\hline & Foreign & -0.088 & 0.024 & -3.677 & $0.000^{* * *}$ \\
\hline & R-squared & \multicolumn{4}{|l|}{0.184} \\
\hline & Adjusted R-squared & \multicolumn{4}{|l|}{0.158} \\
\hline & F-statistic & \multicolumn{4}{|l|}{7.073} \\
\hline & Prob(F-statistic) & \multicolumn{4}{|l|}{$0.000^{* * *}$} \\
\hline \multirow{11}{*}{ ROE } & C & -1.310 & 0.306 & -4.286 & $0.000^{* * *}$ \\
\hline & Size & 0.063 & 0.020 & 3.171 & $0.002^{* * *}$ \\
\hline & COM & 0.015 & 0.026 & 0.591 & 0.555 \\
\hline & Bod & -0.092 & 0.056 & -1.628 & 0.105 \\
\hline & Con & 0.254 & 0.083 & 3.075 & $0.002^{* * *}$ \\
\hline & Inst & -0.044 & 0.058 & -0.750 & 0.454 \\
\hline & Foreign & -0.123 & 0.048 & -2.583 & $0.011^{* *}$ \\
\hline & R-squared & \multicolumn{4}{|l|}{0.134} \\
\hline & Adjusted R-squared & \multicolumn{4}{|l|}{0.105} \\
\hline & F-statistic & \multicolumn{4}{|l|}{4.629} \\
\hline & Prob(F-statistic) & \multicolumn{4}{|l|}{$0.000^{* * *}$} \\
\hline \multirow{11}{*}{ EPS } & C & -1.460 & 0.297 & -4.920 & $0.000^{* * *}$ \\
\hline & Size & 0.079 & 0.020 & 4.031 & $0.000^{* * *}$ \\
\hline & COM & 0.008 & 0.025 & 0.312 & 0.755 \\
\hline & Bod & -0.007 & 0.051 & -0.145 & 0.885 \\
\hline & Con & 0.151 & 0.072 & 2.107 & $0.037^{* *}$ \\
\hline & Inst & -0.049 & 0.060 & -0.827 & 0.409 \\
\hline & Foreign & -0.095 & 0.047 & -2.010 & $0.046^{* *}$ \\
\hline & R-squared & \multicolumn{4}{|l|}{0.150} \\
\hline & Adjusted R-squared & \multicolumn{4}{|l|}{0.123} \\
\hline & F-statistic & \multicolumn{4}{|l|}{5.536} \\
\hline & Prob(F-statistic) & \multicolumn{4}{|l|}{$0.000^{* * *}$} \\
\hline
\end{tabular}

Note: ${ }^{*},{ }^{* *},{ }^{* *}=p$-value $<.10, .05, .01$ 
Table 7: Regression results of the fourth hypothesis

\begin{tabular}{|c|c|c|c|c|c|}
\hline DV & Variable & Coefficient & Std. Error & t-Statistic & Prob. \\
\hline \multirow{12}{*}{ ROA } & $\mathrm{C}$ & -0.487 & 0.143 & -3.421 & $0.001^{* * *}$ \\
\hline & Size & 0.025 & 0.009 & 2.935 & $0.004^{* * *}$ \\
\hline & COM & 0.001 & 0.012 & 0.070 & 0.944 \\
\hline & Bod & -0.010 & 0.024 & -0.434 & 0.665 \\
\hline & Con & 0.142 & 0.034 & 4.214 & $0.000^{* * *}$ \\
\hline & Inst & -0.025 & 0.026 & -0.973 & 0.332 \\
\hline & Foreign & -0.069 & 0.021 & -3.276 & $0.001^{* * *}$ \\
\hline & EM & 2.344 & 0.903 & 2.597 & $0.010^{* *}$ \\
\hline & R-squared & \multicolumn{4}{|l|}{0.219} \\
\hline & Adjusted R-squared & \multicolumn{4}{|l|}{0.190} \\
\hline & F-statistic & \multicolumn{4}{|l|}{7.677} \\
\hline & Prob(F-statistic) & \multicolumn{4}{|l|}{$0.000^{* * *}$} \\
\hline \multirow{12}{*}{ ROE } & C & -0.917 & 0.329 & -2.782 & $0.006^{* * *}$ \\
\hline & Size & 0.060 & 0.020 & 3.004 & $0.003^{* * *}$ \\
\hline & COM & -0.009 & 0.027 & -0.337 & 0.736 \\
\hline & Bod & -0.090 & 0.054 & -1.655 & 0.100 \\
\hline & Con & 0.207 & 0.081 & 2.541 & $0.012^{* *}$ \\
\hline & Inst & -0.021 & 0.059 & -0.355 & 0.723 \\
\hline & Foreign & -0.090 & 0.049 & -1.842 & $0.048^{* *}$ \\
\hline & EM & 5.592 & 2.042 & 2.738 & $0.007^{* *}$ \\
\hline & R-squared & \multicolumn{4}{|l|}{0.162} \\
\hline & Adjusted R-squared & \multicolumn{4}{|l|}{0.130} \\
\hline & F-statistic & \multicolumn{4}{|l|}{5.069} \\
\hline & Prob(F-statistic) & \multicolumn{4}{|l|}{$0.000^{* * *}$} \\
\hline \multirow{12}{*}{ EPS } & C & -1.116 & 0.302 & -3.703 & $0.000^{* * *}$ \\
\hline & Size & 0.080 & 0.018 & 4.338 & $0.000^{* * *}$ \\
\hline & COM & -0.021 & 0.025 & -0.816 & 0.416 \\
\hline & Bod & 0.012 & 0.050 & 0.245 & 0.806 \\
\hline & Con & 0.146 & 0.070 & 2.071 & $0.040^{* *}$ \\
\hline & Inst & -0.043 & 0.056 & -0.774 & 0.440 \\
\hline & Foreign & -0.078 & 0.045 & -1.739 & $0.043^{* *}$ \\
\hline & EM & 5.862 & 1.892 & 3.099 & $0.002^{* * *}$ \\
\hline & R-squared & \multicolumn{4}{|l|}{0.212} \\
\hline & Adjusted R-squared & \multicolumn{4}{|l|}{0.183} \\
\hline & F-statistic & \multicolumn{4}{|l|}{7.381} \\
\hline & Prob(F-statistic) & \multicolumn{4}{|l|}{$0.000 * * *$} \\
\hline
\end{tabular}

Note: ${ }^{*},{ }^{* *},{ }^{* * *}=p$-value $<.10, .05, .01$ 
Raed ALQIREM, Malik ABU AFIFA, Isam SALEH, Fadi HANIAH /

\section{Conclusion}

This study aimed to investigate the relationships between ownership structure, earnings manipulation, and organizational performance, and then examine the role of earnings manipulation as a mediator for the relationship between ownership structure and organizational performance. The study measured the ownership structure through four indicators, namely, board of director ownership, ownership concentration, organizational ownership, and foreign ownership. In addition, this study used three proxies to calculate of organizational performance, namely, return on assets (ROA), return on equity (ROE), and earnings per share (EPS). To explore the role of earnings manipulation as a mediator in the current study model, the earnings manipulation factor was calculated using a modified Jones model based on the measurement of non-discretionary accruals to detect earnings manipulation.

The results revealed that the board of director ownership, ownership concentration, foreign ownership and CEO compensation affect earnings manipulation, while organizational ownership and organization size do not. Subsequently, the earnings manipulation positively affects organizational performance - which was proxied by ROA, ROE and EPS in this study - suggesting managers aimed to increase the organizational performance through opportunistic practices, and thus improved the organization's image.

The results of this study also indicated that ownership concentration, foreign ownership and organization size affect organizational performance proxied by ROA, ROE, and EPS. Ownership concentration and organization size have a positive effect, whereas foreign ownership has a negative effect. At the same time, board of director ownership, organizational ownership, and CEO compensation did not affect organizational performance. According to the agency theory, this could be because several categories of shareholders try to improve the managers' efficiency and the control level in the organization, thus improving its performance.

Finally, this study concluded that including earnings manipulation as a mediator improves the ability of regression models related to the relationship between ownership structure and organizational performance. Besides, earnings manipulation mediates the relationship between ownership concentration and foreign ownership of ownership structure, and organizational performance. Various categories of shareholders contribute in different ways to increase or limit the opportunistic practices in an organization in order to achieve their goals. In addition, the results indicated that, the higher the ownership concentration is, the higher the organizational performance, when mediated by earnings manipulation. Also, the lower foreign ownership is, the higher the organizational performance, when mediated by the earnings manipulation. These results may reflect the extent of contributions by various categories of shareholders in controlling levels in an organization, which affect the organizational performance.

\section{Implications}

The data derived from the current study highlight the relationship between ownership structure, earnings manipulation, and organizational performance, which can be either negative or positive. At the same time, it identifies the role of earnings manipulation as a mediator between ownership structure and organizational performance. Investors and other interested parties can adopt and forecast the deterministic and practical scenarios to identify the extent of earnings manipulation that affects the organizational performance; this could help determine the environmental factors that encourage managers to manipulate earnings. This knowledge can contribute to avoiding incompetence and poor performance that negatively affect the organizational performance and operating continuity in the long term.

The current study proposes that, as ownership structure affects earnings manipulation, policymakers should take this into account to reduce any earnings manipulation and ensure transparency and accuracy in reporting the financial information. Policymakers need to adopt good regulations to limit earnings manipulation, and make sure that financial reports genuinely reflect the situation within the organization. The results of the current study pave the way for more studies into the factors, such as governance practices, that might have an effect on earnings manipulation. At the same time, investors and other interested parties need to comprehend the interaction of other factors that have an effect on the level of earnings manipulation in the organization so as to make efficient decisions.

The data and results show that policymakers and other interested parties could find a way through the ownership structure to reduce earnings manipulation practices. Therefore, the policymakers need to apply regulations, which improve an organization's effectiveness and efficiency, while protecting the investors and other interested parties from risk. Ultimately, the results of this study can help investors and other interested parties in giving them a broader understanding into ownership structure, earnings manipulation, and organizational performance. Further research will be able to provide a wider view of the determinants of earnings manipulation and organizational performance, especially in different areas, such as the MENA region. 


\section{References}

Affan, M. W., Rosidi, E. E., \& Purwanti, L. (2017). The Effect of Ownership Structure on the Quality of Financial Reporting of Manufacturing Companies Listed in the IDX during the Period of 2013-2015. Imperial Journal of Interdisciplinary Research, $3(7), 165-184$.

Afifa, M. A., Alsufy, F., \& Abdallah, A. (2020). Direct and Mediated Associations among Audit Quality, Earnings Quality, and Share Price: The Case of Jordan. International Journal of Economics \& Business Administration (IJEBA), 8(3), 500-516.

Al Saedi, A. (2018). Earnings management and its relationship with stock returns: an empirical study on a sample of Qatari listed industrial companies. Academy of Accounting and Financial Studies Journal, 22(5), 1-12.

Al-Absy, M. S. M., Ismail, K. N. I. K., Chandren, S., \& AlDubai, S. A. A. (2020). Involvement of Board Chairmen in Audit Committees and Earnings Management: Evidence from Malaysia. Journal of Asian Finance, Economics and Business, 7(8), 233-246. https://doi.org/10.13106/jafeb.2020.vol7. no8.233

Alareeni, B. (2018). The impact of firm-specific characteristics on earnings management: evidence from GCC countries. International Journal Managerial and Financial Accounting, 10(2), 85-104.

Alexander, N. (2019). Ownership Structure and Earnings Management. Accounting and Finance Review, 4(2), 38-42.

Al-Khabash, A. A., \& Al-Thuneibat, A. (2009). Earnings management practices from the perspective of external and internal auditors: Evidence from Jordan. Managerial Auditing Journal, 24(1), 58-80.

Almarayeh, T., Aibar-Guzmán, B., \& Abdullatif, M. (2020). Does audit quality influence earnings management in emerging markets? Evidence from Jordan. Spanish Accounting Review, 23(1), 64-74.

Almasarwah, A. (2019). Discretionary accruals and ownership structure: empirical study from Jordan. International Journal of Corporate Governance, 10(3-4), 209-247.

Al-Mousawi, R., \& Al-Thuneibat, A. (2011). The Effect of Audit Quality on the Earnings Management Activities. Dirasat Journal, the University of Jordan, 38(2), 614-628.

Alsufy, F., Afifa, M. A., \& Zakaria, M. (2020). Mediating Effects of Liquidity in the Relationship between Earnings Quality and Market Value of the Share Price: Evidence from Jordan. Review of Applied Socio-Economic Research, 19(1), 17-32.

Andreou, P. C., Louca, C., \& Panayides, P. M. (2014). Corporate governance, financial management decisions and firm performance: Evidence from the maritime industry. Transportation Research Part E: Logistics and Transportation Review, 63, 59-78.

Arif, A., Abrar, A., Khan, M., Kayani, F., \& Shah, S. (2011). Dividend Policy and Earnings Management: An Empirical
Study of Pakistani Listed Companies. Information Management and Business Review, 3(2), 68-77.

Ariyani, H. F., Pangestuti, I. R. D., \& Raharjo, S. T. (2018). The effect of asset structure, profitability, company size, and company growth on capital structure (The Study of Manufacturing Companies Listed on the IDX for the Period 2013 - 2017). Jurnal Bisnis Strategi, 27(2), 123-136.

Baltagi, B.H. (2005). Econometric analysis of panel data (3rd edition). West Sussex: Wiley.

Bao, S. R., \& Lewellyn, K. B. (2017). Ownership structure and earnings management in emerging markets - An institutionalized agency perspective. International Business Review, 26(5), 828-838.

Bassey, E. U., Eleng, D. M., \& Abel, D. Z. (2019). Econometric Examination of Ownership Structure and Financial Performance Indicators of Money Deposit Bank. International Journal of Economics \& Business, 3(1), 42-48.

Berle, A., \& Means, G. (1932). The modern corporation and private property. New York, NY: Harcourt, Brace \& World.

Bolton, P. D., \& Scharfstein, D. (1990). A theory of predation based on agency problems in financial contracting. American Economic Review, 90, 94-106.

Bryman, A., \& Cramer, D. (2002). Quantitative data analysis with SPSS release 10 for Windows: A guide for social scientists. New York, NY: Routledge.'

Burgstahler, D., \& Dichev, I. (1997). Earnings management to avoid earnings decreases and losses. Journal of Accounting and Economics, 24(1), 99-126.

Carslaw, C. A. (1988). Anomalies in income numbers: Evidence of goal oriented behavior. The Accounting Review, 63(2), 321-327.

Chancharat, S., \& Chancharat, N. (2019). Board Structure, Ownership Structure, and Performance of Thai Listed Companies. Australasian Accounting, Business and Finance Journal, 13(3), 53-70.

Chandren, S., Ahmad, Z., \& Ali, R. (2018). Earnings management through accretive share buyback and share price return. International Journal of Advances in Management and Economics, 4(2), 68-73.

Chang, J. C., \& Sun, H. L. (2009). Crossed-listed foreign firms' earnings in formativeness, earnings management and disclosures of corporate governance information under SOX. The International Journal of Accounting, 44(1), 1-32.

Chintrakarn, P., Jiraporn, P., \& Kim, Y. S. (2018). Did firms manage earnings more aggressively during the financial crisis?. International Review of Finance, 18(3), 477-494.

Dang, H. N., Nguyen, T. T. C., \& Tran, D. M. (2020). The Impact of Earnings Quality on Firm Value: The Case of Vietnam. Journal of Asian Finance, Economics and Business, 7(3), 63-72. https://doi.org/10.13106/jafeb.2020.vol7.no3.63

Dechow, P. M., Sloan, R. G., \& Sweeney, A. P. (1995). Detecting earnings management. The Accounting Review, 70(2), 193-225. 
Degeorge, F., Patelm, G., \& Zeckhauser, R. (1999). Earning management to exceed thresholds. The Journal of Business, 72(1), 193-225.

Devin, S., Ara, O., \& Jafari, M. (2019). The Impact of Loans to Deposit Ratio (LTD) and Return on Assets (ROA) on the Capital Adequacy Ratio of the Tehran Stock Exchange and OTC. UCT Journal of Management and Accounting Studies, $7(1), 21-26$

Ding, Y., Zhang, H., \& Zhang, J. (2007). Private vs State Ownership and Earnings Management: Evidence from Chinese listed companies. Corporate Governance, 15(2), 223-238.

Endri, E., \& Fathony, M. (2020). Determinants of firm's value: Evidence from financial industry. Management Science Letters, 10(1), 111-120.

Farooque, O. A., Tony, V. Z., Keitha, D., \& Waresul, K. (2007). Corporate Governance in Bangladesh: Link Between Ownership and Financial Performance. Journal Compilation, 15(6), 1453-1468.

Gong, G., Louis, H., \& Sun, A. (2008). Earnings Management and Firm Performance Following Open-Market Repurchases. The Journal of Finance, 63(2), 947-986.

Gujarati, D. (2004). Basic Econometrics (4th Edition). Singapore: McGraw-Hill Inc.

Guna, W. I., \& Herawaty, A. (2010). The effect of good corporate governance mechanisms, auditor independence, audit quality and other factors on earnings management. Business and accounting journals, 12(1), 53- 68.

Gyampah, K., Boakye, K., Adaku, E., \& Famiyeh, S. (2019). Supplier relationship management and firm performance in developing economies: A moderated mediation analysis of flexibility capability and ownership structure. International Journal of Production Economics, 208, 160-170.

Han, K., \& Suk, D. (1998). The effect of ownership structure on firm performance: Additional evidence. Review of Financial Economics, 7(2), 143-155.

Healy, P. M., \& Wahlen, J. M. (1999). A review of the earnings management literature and its implications for standard setting. Accounting horizons, 13(4), 365-383.

Huynh, Q. L. (2020). A Triple of Corporate Governance, Social Responsibility and Earnings Management. Journal of Asian Finance, Economics and Business, 7(3), 29-40.

Huynh, Q. L., \& Nguyen, N. V. (2019). The effect of prior financial performance on organizational reputation and earnings management. Journal of Asian Finance, Economics and Business, 6(4), 75-81. https://doi.org/10.13106/jafeb.2019. vol6.no4.75

Jaloudi, M. M. (2019). The efficiency of Jordan insurance companies and its determinants using DEA, slacks, and logit models. Journal of Asian Business and Economic Studies, 26(1), 153-166.
Jensen, M., \& Meckling, W. (1976). Theory of the firm: Managerial behaviour, agency costs and ownership structure. Journal of Financial Economics, 3, 305-360.

Jones, J. J. (1991). Earnings management during import relief investigations. Journal of Accounting Research, 29(2), 193-228.

Kao, M. F., Hodgkinson, L., \& Jaafar, A. (2019). Ownership structure, board of directors and firm performance: evidence from Taiwan. Corporate Governance, 19(1), 189-216. https:// doi.org/10.1108/CG-04-2018-0144

Lappalainen, J., \& Niskanen, M. (2012). Financial performance of SMEs: impact of ownership structure and board composition. Management Research Review, 35(11), $1088-1108$

Mahrani, M., \& Soewarno, N. (2018). The effect of good corporate governance mechanism and corporate social responsibility on financial performance with earnings management as mediating variable. Asian Journal of Accounting Research, 3(1), 41-60.

Manzano, M., Conesa, I., \& Sánchez, H. (2014). Keys to reduce earnings management in emerging markets. South African Journal of Business Management, 45, 81-96.

McConnell, J. J., \& Servaes, H. (1990). Additional evidence on equity ownership and corporate value. Journal of Financial Economics, 27, 595-612.

Meek, G. K., Rao, R. P., \& Skousen, C. J. (2007). Evidence on factors affecting the relationship between CEO stock option compensation and earnings management. Review of Accounting and Finance, 6(3), 304-323.

Mellado-Cid, C., Jory, S., \& Ngo, T. (2018). Real activities manipulation and firm valuation. Review of Quantitative Finance and Accounting, 50, 1201-1226.

Mizruchi, M. S. (2004). Berle and Means revisited: The governance and power of large U.S. corporations. Theory and Society, 33(5), 579-617.

Mohrman, M. B. (1996). The use of fixed GAAP provisions in debt contracts. Accounting Horizons, 10(3), 78-91.

Momente, F., Reggiani, F., \& Richardson, S. (2015). Accruals and future performance: Can it be attributed to risk? Review of Accounting Studies, 20(4), 1297-1333.

Morck, R., Shleifer A., \& Vishny, R.W. (1988). Management Ownership and Market Valuation. Journal of Financial Economics, 20, 293-315.

Mostafa, W. (2020). Operating performance and manipulation of accruals. Management Science Letters, 10(5), 985-994.

Mostafa, W., \& Ibrahim, M. (2019). Firm performance and earnings management. Academy of Accounting and Financial Studies Journal, 23(3), 1-11.

Nassar, S. (2018). The Impact of Intellectual Capital on Corporate Performance of IT Companies: Evidence from Bursa Istanbul. Journal of Accounting and Applied Business Research, 1(3), $1-9$. 
Niu, F. F. (2006). Corporate governance and the quality of accounting earnings: a Canadian perspective. International Journal of Managerial Finance, 2(4), 302-327.

Obuobi, B., Li, X., Nketiah, E., Awuah, F., Boateng, E., Sampene, A., Wiredu, J., Ashun, J., Adu-Gyamfi, G., \& Adjei, M. (2020). Relationship between Capital Structure and Banks' Performance; an Evidence of Banks Listed on the Ghana Stock Exchange. International Journal of Econometrics and Financial Management, 8(1), 13-20.

Ogbonnaya, A. K., Ekwe, M. C., \& Ihendinihu, J. U. (2016). Effect of Corporate Governance and Ownership Structure on Earnings Management of Brewery Industry. European Journal of Accounting, Auditing and Finance Research, 4(7), 35-45.

Oswald, S., \& Jahera, J. (1991). The influence of ownership on performance: An empirical study. Strategic Management Journal, 12(4), 321-326.

Pérez, L., Hurtado, J., \& López, F. (2019). Do the institutional environment and types of owners influence the relationship between ownership concentration and board of director independence? An international meta-analysis. International Review of Financial Analysis, 61, 233-244.

Press, E. G., \& Weintrop, J. B. (1990). Accounting-based constraints in public and private debt agreements: Their association with leverage and impact on accounting choice. Journal of Accounting and Economics, 12(1), 65-95.

Ronen, J., \& Yaari, V. (2008). Earning Management, Emerging Insights in Theory, Practice and Research. New York, NY: Springer.

Sakaki, H., Jackson, D., \& Jory, S. (2017). Organizational ownership stability and real earnings management. Review of Quantitative Finance and Accounting, 49(1), 227-244.

Saona, P., Muro, L., \& Alvarado, M. (2019). How do the ownership structure and board of directors' features impact earnings management? The Spanish case. Journal of International Financial Management \& Accounting, 31, 98-133.
Sayari, S., Omri, A., Finet, A., \& Mraihi, F. (2013). The impact of earning management on stock returns: The case of Tunisian firms. Global Journal of Management and Business Research Finance, 13(10), 51-66.

Severin, E. (2001). Ownership structure and the performance of firms: Evidence from France. European Journal of Economic and Social Systems, 15(2), 85-107.

Shirzad, A., \& Haghighi, R., (2015). The effect of corporative leverage on earnings management in the drug industry. Research Journal of Finance and Accounting, 6(17), 119-123.

Short, H., \& Keasey, K. (1999). Managerial ownership and the performance of firms: Evidence from the UK. Journal of Corporate Finance, 5, 79-101.

Sirat, H. (2012). Corporate governance practices, share ownership structure, and size on earning management. Journal of Economics, Business, and Accountancy Ventura, 15(1), 145-156.

Tangjitprom, N. (2012). Earnings Management and Firm Value: The Role of Investor Protection and Corporate Governance. Working Paper. National Institute of Development Administration, Thailand.

Thomas, J. K. (1989). Unusual patterns in reported earnings. Accounting Review, 64(4), 773-787.] https://www.jstor.org/ stable/247861

Walker, M. (2013). How far can we trust earnings numbers? What research tells us about earnings management. Accounting and Business Research, 43(4), 445-481.

Weerathunga, P. R., Xiaofang, C., \& Sameera, T. K. G. (2020). Heterogeneity in Earning Management of Listed Companies Following International Financial Reporting Standards Convergence: A Developing Country Experiences. International Journal of Economics and Financial, 10(1), 101-108.

Wiranata, Y.A., \& Nugrahanti, Y. W. (2013). The effect of ownership structure towards profitability of Indonesia manufacturing companies. Accounting and Finance Journal, 15(1), 15-26. 